\title{
NAGYECSEDI ARTÉZI VIZEK HELYSZÍNI VÍZANALITIKAI VIZSGÁLATA
}

\section{ANALYTICAL EXAMINATIONS OF WATER SAMPLES FROM ARTESIAN WELLS AT NAGYECSED}

\author{
Fórián Sándor $^{1}$, Szalai László ${ }^{2}$, Bodnár Ildikó $^{3}$ \\ ${ }^{I}$ Debreceni Egyetem, Müszaki Kar, Környezet- és Vegyészmérnöki Tanszék, \\ 4024, Magyarország, Debrecen, Ótemetö utca 2- 4 sz; Telefon / Fax: +36-52-415- \\ 155/77830,levelezési cim: forian@eng.unideb.hu \\ ${ }^{2}$ Diehl Aircabin Hungary Kft. 4300, Magyarország, Nyírbátor, Ipari Park utca 9 \\ szalailacsi1993@gmail.com \\ ${ }^{3}$ Debreceni Egyetem, Müszaki Kar, Környezet- és Vegyészmérnöki Tanszék, \\ 4024, Magyarország, Debrecen, Ótemetö utca 2- 4 sz; Telefon / Fax: +36-52-415- \\ 155/77825, levelezési cim: bodnari@eng.unideb.hu
}

\begin{abstract}
Water from an artesian well or spring is usually cold and free of organic contaminants, making it desirable for drinking. We examined the quality of the artesian wells in the city of Nagyecsed. Our aims was to examine the water samples in situ and to determine the status of the artesian water based on the measured data. We examined 9 artesian wells. At the sampling points the following parameters were determined by the MultiLine $\mathrm{P} 4$ portable equipment: $\mathrm{pH}$, oxidation reduction potential, electrical conductivity, salinity, dissolved oxygen concentration, dissolved oxygen saturation. The in situ measurements provide a rapid and reliable method. We determined relevant water flow of wells. Our measurements in the spring, summer and autumn was repeated, the results were evaluated. As a result, it can be said that the wells are suitable based on the measured on situ parameters for human consumption.
\end{abstract}

Keywords: artesian wells, Nagyecsed, MultiLine P4 portable equipment, the relevant water flow, in situ measurement.

\section{Összefoglalás}

Az artézi kutak vize általában szennyeződésmentes, és kiválóan alkalmas fogyasztásra. Nagyecsed városának kútjai által biztosított artézi vizek minőségét vizsgáltuk. Célunk az volt, hogy helyszíni mérésekkel megállapítsuk a feltörő víz kémiai minőségét és fogyaszthatóságát. Kilenc kutat vizsgáltunk a településen. A MultiLine P4 terepi mérőbőrönd segítségével meghatároztuk a vizek pH értékeit, fajlagos elektromos vezetőképességeit, ill. sótartalmát, valamint az oxigén háztartási viszonyait (oldott oxigén mennyisége és százalékaránya) Ezek a helyszíni mérések gyors és megbízható képet nyújtanak a vizsgált vizek kémiai állapotáról. Ezen kívül egyszerü méréssel a kutak vízhozamát is meghatároztuk. A méréseket tavasszal, nyáron és ősszel is megismételtük, ezek eredményeit értékeltük.

Kulcsszavak: artézi kút, Nagyecsed, MultiLine P4 terepi méröbörönd, vizhozam, helyszíni mérés. 


\section{Bevezetés}

A rétegvíz egyik jellegzetes típusa az artézi víz. Üledékes medencék rétegzett porózus vízadó képződményeiben két vízzáró réteg között hidrodinamikus nyomás alatt lévő vízféleség [1]. Megcsapolásakor (kút, akna, földalatti létesítmény) a réteg fedővonalával magasabbra, a medence morfológiájától függő mértékig felemelkedik [2]. Munkánk során Nagyecsed város artézi kútjainak vizeit vizsgáltuk.

\subsection{A vizsgált terület bemutatása}

Nagyecsed Magyarországon az Észak alföldi régióban, Szabolcs-Szatmár-Bereg megyében, a Délkelet-Nyírségben elhelyezkedő város a Kraszna folyó partján, mely a Mátészalkai járáshoz tartozik. Területe 4385 ha (hektár), népessége 6524 fő [3]. A település területén számos artézi kút található, melyek vizét a lakosság elöszeretettel fogyasztja. A helyi önkormányzat sok kutat turisztikai látványosságként kezel, ezeket felújítatta, és rendszeresen karbantartja. Egy-egy régi, a környékre jellemző hagyományt viselnek az egyes kutak a nevükben (pl.: Lovas kút Betyárok kútja vagy Villanytelepi kút).

\section{Anyag és módszer}

A helyszíni vízkémiai méréseket három különböző évszakban végeztük, 2016. március 10-én, június 16 -án, és szeptember 14én. A mérömüszert a mérések elkezdése elött kalibráltuk, ezt követően a kutak vizéből merítős módszerrel mintát vettünk, amin elvégeztük a megfelelő paraméterek mérését. Ezek a következőek voltak:

$-\mathrm{pH}[-]$;

- hömérséklet $\left[{ }^{\circ} \mathrm{C}\right]$;

- fajl. elektr. vezetőképesség $[\mu \mathrm{S} / \mathrm{cm}]$;

- sótartalom [g/l];

- oldott oxigén tartalom [mg/l; \%];

- vízhozam $\left[\mathrm{m}^{3} / \mathrm{h}\right]$.
A készülék olyan paraméterek mérésére nyújt lehetőséget, melyek egy mintavételt követően folyamatosan változnának. Továbbá egy helyszínen kapott kiugró érték alapot adhat egy átfogó laborvizsgálatra, vagy az esetlegesen bekövetkezett szennyezés elhárítására, kármentesítésére. A készülék két fö részegységből áll: a mérőműszer mely a jelfeldolgozást végzi, és a mértértékeket megjeleníti és tárolja. Illetve az opcionálisan csatlakoztatható mérőfejek (vezetőképesség- mérö cella, pH kombinált elektróda, oldott oxigénérzékelő). A mintavételekről terepi jegyzőkönyvet készítettünk, ami segítségünkre volt a későbbi értékeléseknél. A jegyzökönyvben rögzítettük a helyszíni adatokat, az aktuális meteorológiai adatokat, valamint köbözéssel megmértük a kutak vízhozamát is.

\section{Eredmények és azok értékelése}

A helyszínen mért adatokat kiértékeltük és szemléltetésképpen a fontosabbakat külön diagramon ábrázoltuk. Tekintettel arra, hogy a lakosság és az idelátogató turisták ivóvízként fogyasztják ezen artézi kutak vizeit, a vizsgálataink eredményeit az érvényben lévő, és ivóvízre vonatkozó rendeletekkel, törvényekkel meghatározott határértékekkel vetettük össze.

\subsection{A pH mérése, eredményei}

A vizek minősítésénél fontos paraméter a pH, amely mérése kombinált üvegelektród segítségével potencimetriás módszerrel történt. Ez egybeépítve tartalmazza a mérő és a referencia elektródot is. A jogszabályban foglaltak szerint a $\mathrm{pH}$ értéke a 6,5 és 9,5 közötti tartományba kell, hogy essen ivóvizek esetén. A mért értékeink alapján elmondhatjuk, hogy egyetlen esetben sem volt határérték túllépés. A pH értékek 7,04 és 7,70 tartományban mozognak, így a rendeletben erre a paraméterre meghatározott elöírásoknak az összes vizsgált kút vize megfelel. 


\subsection{A fajlagos elektromos vezetôké- pesség és értékelése}

A fajlagos elektromos vezetőképesség az oldat fajlagos ellenállásának reciprok értéke, mely két, egyenként $1 \mathrm{~cm}^{2}$ felületü, egymástól $1 \mathrm{~cm}$ távolságra lévő elektróda közötti oldatban mérünk. Egysége az $1 \mathrm{~cm}-$ re vonatkoztatott mikrosiemens $(\mu \mathrm{S} / \mathrm{cm})$. A fajlagos elektromos vezetőképességet több tényező is befolyásolja, függ az oldat hömérsékletétől, az oldatban lévő anionok és kationok fajtájától és mennyiségétől, valamint a disszociáció fokától [4]. A tiszta víz vezetőképessége igen kicsi, hiszen benne az oxónium- és hidroxid-ionok koncentrációja is kicsi.

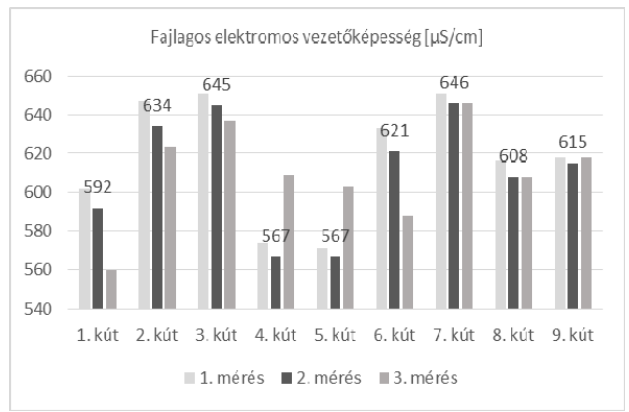

1. ábra. A mért fajlagos elektromos vezetöképesség értékek diagramja

Az ivóvíz paramétereinek határértékeit a 201/2001 (X.25.) Korm. rendelet határozza meg [5]. A fajlagos elektromos vezetőképesség értékénél a jogszabály szerint a maximálisan elfogadható érték: $2500 \mu \mathrm{S} / \mathrm{cm}$ $20{ }^{\circ} \mathrm{C}$-on (Jogszabály 1. melléklete). Az 1. ábrán jól látható, hogy minden vizsgálati értékünk a vonatkozó határérték alatt helyezkedik el $(506-651 \mu \mathrm{S} / \mathrm{cm})$, így ez a paraméter is megfelel a vele szemben támasztott elöírásoknak.

\subsection{Sótartalom vizsgálata}

A rétegvizek rendkívül változó sótartalommal bírnak. Ez annak a következménye, hogy a vizet tároló kőzettömbök milyen geológiai tulajdonságokkal bírnak. Ennek értéke Magyarországon 10-20000mg/l között van.

A sótartalom terepen mért értéke kiegészitő paraméterként jelenik meg. Egy viszonyítási alapként szolgál a későbbiekben az ionkromatográfiás iontartalom meghatározásához (IC). Felvilágosítást nyújt arról, hogy a vizsgált mintákban hozzávetőlegesen milyen mértékben találhatóak meg a különféle sóformák. A mérömüszerünk $\mathrm{g} / \mathrm{l}$ egységben méri a sótartalmat, így csak tájékoztató jelleggel bírnak az információk. Mint az táblázatban jól látható (1. táblázat) több esetben méréshatár alatt volt a ténylegesen mérhető sótartalom. Ezeket az értékeket a táblázatban * jellel jelültük

1. táblázat. A kutak vizében mért sótartalom $g / l$

\begin{tabular}{|c|c|}
\hline Kút száma & $\begin{array}{c}\text { Mért átlagos só- } \\
\text { tartalom }\end{array}$ \\
\hline 1-es kút & $0 \mathrm{~g} / 1^{*}$ \\
\hline 2-es kút & $0,7 \mathrm{~g} / 1$ \\
\hline 3-as kút & $0,1 \mathrm{~g} / 1$ \\
\hline 4-es kút & $0 \mathrm{~g} / 1^{*}$ \\
\hline 5-ös kút & $0 \mathrm{~g} / 1^{*}$ \\
\hline 6-os kút & $0,03 \mathrm{~g} / 1$ \\
\hline 7-es kút & $0,1 \mathrm{~g} / 1$ \\
\hline 8-as kút & $0 \mathrm{~g} / 1^{*}$ \\
\hline 9-es kút & $0 \mathrm{~g} / 1^{*}$ \\
\hline
\end{tabular}

A táblázatban feltüntetett mért értékek alapján elhatároztuk, hogy a későbbiekben ionkromatográfiás mérésekkel kívánjuk meghatározni a só képzésre hajlamos ionok $\left(\mathrm{Na}^{+}, \mathrm{Ca}^{2+}, \mathrm{K}^{+}, \mathrm{Mg}^{2+}\right.$, ill $\mathrm{Cl}^{-}, \mathrm{SO}_{4}{ }^{2-}$ stb. $)$ mennyiségét.

\subsection{Az oxigéntartalom mérése}

A víz egyik fontos tényezője, a vízben lévő oldott állapotú oxigén, és annak menynyisége.

A mért eredményeinket megadhatjuk koncentrációban (mg/l), vagy százalékos telítettség értékben (\%). A gyakorlatban minden folyadék tartalmaz valamennyi oldott oxigént. Minden folyadék annyi oxi- 
gént vesz fel, ameddig a folyadékban lévő oxigén parciális nyomása egyensúlyba kerül a vele érintkező levegő, illetve gázfázissal. A tényleges oxigén-koncentrációt számos tényező határozza meg, pl. a hőmérséklet, a légnyomás, a mikrobiológiai lebontási folyamatok oxigén- felhasználás, illetve az algák oxigéntermelése stb.

Problémát jelenthet, hogy a vízminta oldott oxigén koncentrációja szállítás közben változhat, így természetes vizek esetén, a mérést a mintavétel helyszínén célszerü elvégezni. A víz aktuális oldott oxigéntartalma, a víz minőségét akkor jellemzi a legjobban, ha nem a koncentrációját, hanem telítettségi százalékban kifejezett mennyiségét adjuk meg. Az oxigéntartalom ilyen módon megadott értéke a víz biokémiai állapotát jellemzi, teljes (100\%) telítettséghez képest. Az eltérés megmutatja, hogy a vízben vannak-e jelen oxigént fogyasztó, vagy termelö szervezetek [6]. Az oldott oxigén tartalomra vonatkozó mért eredményeinket a $\mathbf{2}$. ábrán mutatjuk be.

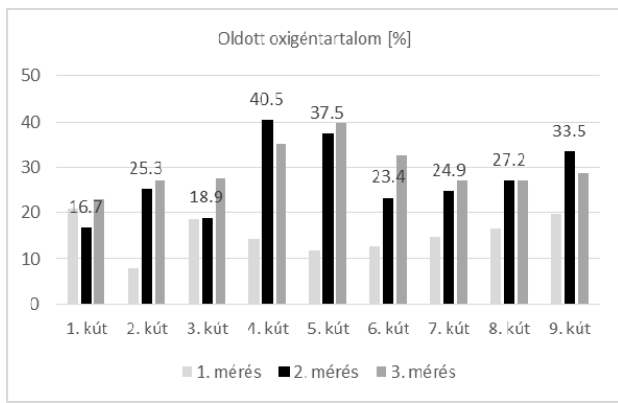

2. ábra. Az oldott oxigéntartalom \%-os telitettség értékeinek diagramja

Az oxigén háztartás mérése során az egyes mérési eredmények közötti eltérés csekély volt, kiugró értékkel nem találkoztunk. Minden esetben $5 \mathrm{mg} / \mathrm{l}$ érték alatt mértünk.

Az egyes kutak vizének a különböző évszakokban való mérése során különösebb változás nem volt érzékelhető. Az általunk mért eredmények a 10/2010. ( VIII.18.) VM rendelet szerinti határértéknek megfeleltek. Oxigéntartalmat jelentősen csökkentő antropogén hatást nem tapasztaltunk.

\subsection{A kutak vízhozamának meghatá- rozása}

A településen található kutak vízhozamát köbözéssel (térfogatmérés elvén alapuló közvetlen vízhozam-mérés) határoztuk meg. Az ismert térfogatú edény (20 literes vödör) megteléséhez szükséges időből, a térfogat ismeretében számoltuk a vízhozamokat. Az egyes kutak vízhozama $0,38-1,85 \mathrm{~m}^{3} / \mathrm{h}$ között volt, a vizsgálati időszaktól függetlenül.

\section{Következtetések}

Nagyecseden az artézi kutak vize jó minőségü az általunk mért kémiai komponensek tekintetében, nem lépik túl a honi határértékeket. Eddigi eredményeink igazolták azt, hogy a kutak vize alkalmas ivóvízfogyasztásra. További célunk ionkromatográfiás vizsgálatok elvégzése különféle ionok meghatározásához.

\section{Szakirodalmi hivatkozások}

[1] Beczner, J. Környezet- és természetvédelmi lexikon (Encyclopaedia of environmental and natural protection) Vol. I-II. Acta Alimentaria, 31(2), 2002, 205-206.

[2] Juhász, J. Hidrogeológia, Akadémiai Kiadó, Budapest, 2002, 1176.

[3] Szállási, Á., Gazda, I., \& Bodorné Sipos, Á. II. Rákóczi Ferenc és Ecsed. Magyar Tudománytörténeti Intézet-Nagyecsed Város Önkormányzata, 2008, 169.

[4] Szücs, P., Sallai, F., Zákányi, B., \& Madarász, T. Vízkészletvédelem, A vízminőség - védelem aktuális kérdései. Bíbor Kiadó, 2009, 1-418.

[5] 201/2001. (X. 25.) Korm. rendelet. az ivóvíz minőségi követelményeiről és az ellenőrzés rendjéről, Budapest, 2001.

[6] Dr. Percsich K. Bevezetés az vízanalitikába (SZIE MKK Központi Laboratórium, Gödöllö, 2005. 163. 